\title{
SouthEastAsia RESEARCH
}

\section{Change in frequency}

With effect from Volume 5 (1997), South East Asia Research will be published three times a year. Cover dates will henceforth be March, July and November.

This increase in frequency is a reflection of increased demand - from authors keen to publish in a journal dedicated to an area studies approach and from the ever growing list of subscribers.

Recent articles in South East Asia Research have included:

A 'New Sabah' and the spell of development: resolving federal-state relations in Malaysia'

Francis Loh Kok-Wah

Vietnam from the 1890s to the 1990s: continuity and change in the longer perspective

Ralph Smith

Electoral participation by southern Thai Buddhists and Muslims

Robert B. Albritton et al

The place of the Kadayan in traditional Brunei society

Allen R. Maxwell

International tourism in Java, 1900-1930

Robert Cribb

One year subscription ( 3 issues): Institutions: world excluding the USA, £76; USA, \$114. Individuals (personal cheque only): world excluding the USA $\mathfrak{f 3 0}$; USA, \$45.

For subscription orders or a free sample copy contact:

In Print Publishing Ltd, Turpin Distribution Ltd, Blackhorse Road, Letchworth, Herts SG6 1HN, UK. Tel: +44 1462672 555. Fax: +44 1462480 947. E-mail: TURPIN@RSC.ORG

For article submissions contact: Dr Ian Brown, Editor, South East Asia Research, Department of History, SOAS, Thornhaugh Street, Russell Square, London WC1H 0XG, UK. 


\section{Recent articles:}

Civil Society in South Korea: From Grand Democracy Movements to Petty Interest Groups?

Sunhyuk Kim

An Age of Uncertainty: Building a PostCold War U.S. Security Strategy for East and Southeast Asia

\section{Alexander A. Sergounin}

Dollars and Democracy in Hong Kong:

Understanding the Logic of Chinese Policy

Kevin P. Lane

International Relations Theory and Japanese Pacifism: Why Didn't Tokyo Go Ballistic Over North Korean Nukes? Jeremy D. Mayer

\section{Young C. Kim} EDITOR

The Gaston Sigur Center for East Asian Studies and The George Washington University
Amolyses of social, political, exomomic, and mililury

deócloplnumbin post-Worla War II

Norlhoust Asin and

of external finctors likely lo hato' a significant imlunt on Chima, Japan, andKorin.

\section{JOURNAL OF NORTHEAST ASIAN STUDIES}

\section{Published Quarterly}

\section{Subscription rates:}

Individuals: $\$ 48 / y \mathrm{r} ; \$ 90 / 2 \mathrm{yrs} ; \$ 128 / 3 \mathrm{yrs}$

Institutions: $\$ 112 / \mathrm{yr}$; $\$ 208 / 2 \mathrm{yrs} ; \$ 288 / 3 \mathrm{yrs}$

Foreign surface mail add $\$ 32 / \mathrm{yr}$

Foreign airmail add $\$ 48 / \mathrm{yr}$

(Rates subject to change annually)

Visit us on the web at

http://WWW.TRANSACTIONPU8.COM

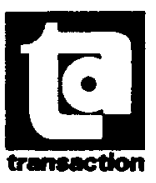

TRANBACTION PUBLIBHERB DEPARTMENT 2097

RUTGERS-THE STATE UNIVERSITY NEW BRUNSWICK, NEW JERSEY 08903 